\title{
Bank Loan and Performance of Firms Listed at the Nairobi Securities Exchange
}

\author{
Moses Odoyo Owili ${ }^{*} \quad$ Luther Otieno Odhiambo ${ }^{2}$ \\ Department Finance and Accounting, University of Nairobi, PO box 30197, Nairobi 00100, Kenya
}

\begin{abstract}
This study was to establish the effect of bank loan on firm performance, the link being cost of capital and banking relationship. Firms might source valuable advice from their bankers. That advice can add value or not and is a subject of empirical investigation. This study was carried out on all the 65 listed companies at Nairobi Securities Exchange (NSE) between 2013 and 2017. There is relationship, between bank's loans to total asset ratio and firm performance, for a group, when return on assets (ROA) is employed as a measure of performance. There is no relationship when return on equity (ROE) is used as a measure of performance. It is difficult concluding that bank loan influence performance. It is possible that banks offer services to their client indiscriminately. It is not important looking at the direction of the relationship between bank loan and performance. In conclusion, firms cannot rely on bank loans and their relationship with bankers to edge out their competitors and earn superior returns. Keywords: Bank loan; Return on Common Equity; Return on Assets
\end{abstract}

DOI: $10.7176 /$ RJFA/11-10-05

Publication date:May $31^{\text {st }} 2020$

\section{Introduction}

Bank loan is a type of debt whose benefits to organization need to be examined given that the effect of debt on firm performance is not conclusive. The cost of capital used to discount earnings to arrive at firm value include cost of debt, that is, weighted cost of capital. Barrier in accessing loan and might affect performance by deny firms professional advice that banks offer (Schiffer and Weder, 2001).

Miller and Modigliani (1958) model suggest that debt capital does not add value to the firm. Brigham and Gapenski (1996) argue theoretically that Miller and Modigliani (1958) model is appropriate but in real-life situation, bankruptcy costs do stay alive and that these costs are directly comparative to the debt levels in a firm. Miller and Modigliani (1958) agreed that real-life distortions make debt capital relevant. This proposition implies association between bank loan and performance of a firm; which can be tested empirically. Fama, (2002) states that the benefits of debt funding consist of tax advantage of using debt and complimentary cash flow. Debt financing costs may include bankruptcy costs and the agency costs. Managers strike a balance between corporate tax advantage debt and the bankruptcy costs (Kraus and Litzenberger, 1973) and agency costs (Jensen and Meckling, 1976).

\subsection{Bank Loan}

In developing economies, bank finance takes the form of loans from banks, bank overdrafts and trade factoring (Organization for economic Cooperation and Development, 2006; Rungani, 2009). Banks manage loans effectively because they have information advantage and enjoy economies of scale; and these explains why banks are referred to as delegated monitors (Saunders and Cornett, 2018).

Banks cost effectively link lenders and borrowers by providing a brokerage function and through asset transformation. Banks also offer advisory services, which help depositors and lenders reduce information costs. In the words of Saunders and Cornett (2018) 'the asset transformation function is accomplished by issuing their own securities, such as deposits and insurance policies that are more attractive to household savers, and using the proceeds to purchase the primary securities of corporations. Thus, FIs take on the costs associated with the purchase of securities. In Kenya, inadequate access to bank loan is a top factor affecting the performance of listed firms (Wanjohi \& Mugure, 2008).

\subsection{Firms Performance}

Financial performance measurements revolve around return on total assets, asset turnover, residual income, return on equity and economic value added (Stewart, 1991). Ideally firm performance depends on the asset's management and not necessarily how the assets are financed. However, Myers (1977) trade off theory explains how debt capital enters a firm's performance.

However, firm performance depends on other fundamental factors, which include fiscal and monetary policy, technological advancement, productivity of employees and banks can advise firms on such issues. Banks are of different monitoring and advisory capacities, and one would expect variations in a borrower's performance to be partly explained by the quality of monitoring and advice from a bank. That quality monitoring and advice are obtainable from the lending bank, and that is how a bank loan enters performance. 
Buch (1998) gave some insights into the sources of private information associated with banks, which can reduce agency costs. Firm history with the bank in terms of deposits and loan repayment are exploited by banks in advising and transacting with firms (Buch, 1998). However, ownership of private information by banks may also lead to a conflict of interest, to the disadvantage of borrowing firm. It gets worse when confidential information about a firm is disclosed to competitors. Hassan, Khan and Wazir, (2016) study connect long-term debt to return on assets, concluding high debt is associated with lower profitability.

\subsection{Research Problem}

Bank has a cost that impact on the profitability of the borrowing firm. Firms that borrow can get financial advice from banks. There is a tradeoff between the benefits and cost of bank loan. Agnew (2003) suggests that loan is the recipe for any growth of business enterprises because firms require enough capital. Bank loan is said to add value if forms with a bank loan outperform those without a bank loan.

Compared to borrowing from the public, firms that borrow from banks expect, apart from the amount loaned, additional benefits from the bank. Bank advice to and monitoring of a borrowing firms lower operating cost. Nevertheless, bank loans expose firms to costly bankruptcy. Therefore, empirical studies on the effect of bank loan on performance are required.

Ngobo \& Capiez (2004), Eriotis et al., (2002); Goddard et al., (2005) indicated a negative debt financing effect on the firm financial performance. Berger \& Bonaccorsi (2006), Baum et al. (2006) and (2007) exhibited a positive impact. Weill (2008), Simerly and LI (2000), and Mesquita \& Lara (2003) found both negative and positive effects in their studies. A non-significant effect was established by Baum et al. (2007) in the industrial companies in American. Intuitively banks adopt standard practices and are highly regulated that it is not possible that advantages to firms transacting with them will vary from firm to firm. These are mixed results. Furthermore, if bank loan matter, then there should be visible differences in performance across firms with different levels of bank loan. This study is an answer to the following question: what is the effect of bank loan on performance of listed firms at the NSE?

\section{Literature Review}

The core capital structure theories are Modigliani and Miller (1958, 1963) trade-off theory, Jensen and Meckling, (1976) agency theory and by Myers (1984) pecking order theory. These theories anchor effect of bank loan on performance, (Sogorb-Mira, 2002). Miller and Modigliani, (1958) made their point about use of debt in their proposition called the "irrelevance theorem," which stated that capital structure could not change the firm's market value. Miller \& Modigliani, (1958) theory was revised in 1963 to symbolize the actual state of affairs. They came up with the effect of interest tax deductible, which is cash saving that translates into the increased value of the firm.

Jensen and Meckling, (1976), explain agency cost in terms of conflict between managers and shareholders; which extend to debt holders and equity holders; the source of disagreement is the separation of management from ownership. These conflicts must be managed, and it is suggested that debt mitigates agency costs and therefore, add value to the firm. Myers (1984) suggest that management tends to give priority to internal financing before the external financing because internal financing has cost advantages over other sources of finance that include bank loan.

The link between a bank loan to firm performance is banking relationships (Peltoniemi, 2004). Banking relationships are expressed through interest engagements, Bolton and Freixas, (2000), and through services offered by the bank (Degryse and Cayseele, 2000). Establishment of excellent relationships with banks should enhance borrower's business reputation, reduce information leakages to the competitors, (Campbell, 1979), and reduce the impact of asymmetric information between the bank and borrowing firm (Diamond, 1984 and Bolton and Freixas, 2000). Bank relationship might limit conflicts emanating from financial intermediation (Deloof \& Vermoesen, 2010), increase access to loan facility at affordable cost (Houston \& James, 1996 and Pertersen \& Rajan, 1995).

Strong banking relationship gives the bank opportunity to carry out dynamic monitoring thus reducing freeriding and information asymmetry (Diamond, 1984). Furthermore, close banking relationship through frequent lending boost borrowing firm image and this explain firms prefer funding from the bank. A firm with integrity can cost effectively raise funds in capital markets (Diamond, 1991; Kutsuna et al., 2003). Hoshi et al, (1990) suggested that structuring relationships with banks helps firms rise above business or financial distress.

Firms do not automatically obtain profit from creating close ties with banks as such relationship can be risky. In sustainable relationships building processes, banks act as custodian of important and sensitive information associated to the firm's performance and should there be leakages of sensitive information availed to competitors deliberately or involuntarily, then the borrowing firm is disadvantaged (Berger \& Udell, 1998). The familiarity can be exploited by the lender to adversely charge high interest (Suwannaporn, 2003). Sharpe (1990), Thadden (1995), Greenbaum et al., (1989), and Rajan (1992) borrower lender relationship might result into an information lock-in problem, that is, the lender is costly tied to a particular bank. Banks may make a sound decision to lengthen a loan further in order to make recoveries of preceding loan and this overcomes financial distress (Boot, 2000). 
Banking relationships enhances firm value in terms of and business performance and the growth (ROA), (Rajan, 1992); and return to shareholders (ROE) (James, 1987). Castelliet al, (2006) found that profitability of firms (ROA \& ROE) responds negatively to lackluster bank relationships. In a study in Taiwan, Fok, (2004) report positive relationship between firm performance and foreign-bank relations, and that there is negative relationship with domestic-bank. Teruel and Solane (2008) did an investigation on a SMEs company in Spain on cash worth and established that firms with advanced quantity of short-term debt experience high levels of cash. Jaramillo and Schiantarelli (2002) in their study in conclude that a loan of shorter maturity was not favorable to firms. Therefore, long-term debt adds value to firms.

\section{Data Analysis and Results}

This study is over the period 2013 to 2017 and over that period, there were sixty five listed firms. The required data was extracted from audited annual reports and statement of accounts. The measures of performance were return on assets (ROA), return on equity (ROE) and level of usage of bank loan is measured by the ratio, bank loan to total assets (BLTA). Bank loan to total assets (BLTA) ratio was used to categorize the firms in the study into three groups, namely, high bank loan (2), medium bank loan (1) and low bank loan (0). The equation describing the relationship is as presented below:

Performance $(\mathrm{ROA})=\alpha+\beta$ BLTA $+\varepsilon$; an Performance $(\mathrm{ROE})=\alpha+\beta$ BLTA $+\varepsilon$

Where:

$\alpha$ - The y intercept and is change in performance when there is no bank loan.

$\beta_{1}$ - The sensitivity coefficient that is the rate of change in performance when there is a change in bank loan,

$\varepsilon$ - The error term; the effect of all other variables not captured by the study model.

The data input in this model is categorical and General Linear Model (GLM) is used to compare performance across different levels of borrowings, namely high (2), medium (1) and low (0).

\subsection{Descriptive Statistics}

The descriptive statistics are as presented in table 1 below. From table 1 the data show that the range of use of bank loan to finance total asset's ranges between two (2) percent to eighty five (85) percent, the latter is evidently owned by the bank(s). The mean usage of loan is about twenty-six (26.3) percent and is closer to minimum value of two percent than the maximum value; meaning that the data is skewed to the left and that usage of bank loans does not vary much across the firms studied.

\begin{tabular}{|c|c|c|c|c|c|}
\hline & $\begin{array}{l}\mathrm{N} \\
\text { Statistic }\end{array}$ & $\begin{array}{l}\text { Min } \\
\text { Statistic }\end{array}$ & $\begin{array}{l}\text { Max } \\
\text { Statistic }\end{array}$ & $\begin{array}{l}\text { Mean } \\
\text { Statistic }\end{array}$ & $\begin{array}{l}\text { Std. Deviation } \\
\text { Statistic }\end{array}$ \\
\hline Bank Loan to Total Assets Ratio & 53 & 0.02 & 0.85 & 0.263 & 0.202 \\
\hline Return on Assets & 54 & -0.18 & 0.23 & 0.057 & 0.089 \\
\hline Return on Equity & 54 & -2.08 & 0.76 & 0.099 & 0.359 \\
\hline
\end{tabular}

Valid N (listwise)

The standard deviation of about twenty (20.02) percent confirms low dispersion in this ratio. The lowest return on assets (ROA) is a loss of eighteen (18) percent, and the highest profit of twenty-three (23) percent; a lower standard deviation of about nine (8.9) percent suggests an even distribution for this variable. The average return on assets is about six (5.7) percent. The lowest return on equity (ROE) is a loss of about two hundred (208) percent, and the highest is a profit of seventy six (76) percent, with a mean of about $10(9.9)$ percent; the standard deviation of ROE is the highest at about 36 (35.9) percent.

The correlation between bank loan to total asset ratio and ROA is -0.313 , with a p-value of 0.002 is statistically significant. This suggests that as bank loan increase's return on assets decreases. P-value of 0.05 . The correlation between a bank loan to total asset ratio and ROE is not statistically significant. We should not expect any relationships between ROE and bank loan.

3.1.1 Return on Assets (ROA) and Bank Loan

In this section are the results on the test on whether performance of the firms in this study depends on the level of bank loan. The first hypothesis test the relationship between levels of performance, measured as ROA and level of bank borrowing. The case wise summary results are in table 2 . 
Table 2: Return on Assets (ROA) across Levels of Bank Loans

\section{Bank Loan Classification}

High $(60 \%-100 \%)$

Medium (31\% - 59.9\%)

Low $(0 \%-30.99 \%)$

Total
ROA

$\mathrm{N}$
Grouped Median

(Mean)

$\begin{array}{lr}0.0027 & 4 \\ 0.0415 & 23 \\ 0.0788 & 26 \\ 0.0569 & 53\end{array}$

Std. Deviation

0.1227

0.1110

0.0553

0.0901
0.0413

0.0680

0.0700

0.0664

In table 2, the average return for asset (ROA) for all groups is 5.69\%. The group in which $0 \%$ to $30.99 \%$ of total assets are financed with a bank loan, that is the group with low bank loan, have an average ROA of 7.88 percent and it is the highest. The data tell us that firms with a low bank loan to the total asset ratio outperform the other groups.

The group in which $60 \%$ to $100 \%$ of total assets are financed with a bank loan, that is the group with highest bank loan, have an average ROA of 2.7 percent and it is the lowest. The data tell us that firms with a high bank loan to the total asset ratio underperform relative to the other groups. However, test on whether the ROA across different loan levels is necessary and is presented in Tables 3, 4, 5, 6, 7and 8. The Levene's test for equality of variances and t-test for equality of means is used.

In table 3 present results for test in difference in ROA between firms with high $(60 \%-100 \%)$ bank loans to those with medium $(31 \%-59.9 \%)$. Using Levene's test for equality of variances, with F- value of 0.00 and pvalue of 0.995 which beyond cut off 0.05 , the variances of these two groups are the same and not significantly different.

From the group statistics on table 3, firms classified as of medium loan has a higher mean ROA than those classified high bank loan, but the mean difference in ROA of -0.039 or negative 3.9 percent between the groups is not statistically significant, because the t-test for equality of means has a t-value of -0.639 , which is lower than the cut-off of +2 or -2 . Therefore, the data tell the performance of the firm, measured as ROA, is not different between the two groups.

Table 3. Independent Samples Test for Difference in ROA between Firms with High Bank Loans to Those with Medium Bank Loans

\begin{tabular}{|c|c|c|c|c|c|c|c|c|c|c|}
\hline & \multicolumn{2}{|c|}{$\begin{array}{l}\text { Levene's Test } \\
\text { for Equality of } \\
\text { Variances }\end{array}$} & \multicolumn{7}{|c|}{ t-test for Equality of Means } \\
\hline & & \multirow[t]{2}{*}{$\mathrm{F}$} & \multirow[t]{2}{*}{ Sig. } & \multirow[t]{2}{*}{$\mathrm{t}$} & \multirow[t]{2}{*}{$\mathrm{df}$} & \multirow[t]{2}{*}{$\begin{array}{l}\text { Sig. (2- } \\
\text { tailed) }\end{array}$} & \multirow[t]{2}{*}{$\begin{array}{l}\text { Mean } \\
\text { Diffe- } \\
\text { rence }\end{array}$} & \multirow{2}{*}{$\begin{array}{l}\text { Std. } \\
\text { Error } \\
\text { Diffe- } \\
\text { rence }\end{array}$} & \multicolumn{2}{|c|}{$\begin{array}{l}95 \% \text { Confidence } \\
\text { Interval of the } \\
\text { Difference }\end{array}$} \\
\hline & & & & & & & & & Lower & Upper \\
\hline \multirow{2}{*}{$\begin{array}{l}\text { Return } \\
\text { on } \\
\text { Assets }\end{array}$} & $\begin{array}{c}\text { Equal } \\
\text { variances } \\
\text { assumed } \\
\end{array}$ & 0.00 & 0.995 & -0.639 & 25 & 0.529 & -0.039 & 0.0609 & -0.164 & 0.0866 \\
\hline & $\begin{array}{c}\text { Equal } \\
\text { variances } \\
\text { not assumed }\end{array}$ & & & -0.593 & 3.9 & 0.586 & -0.039 & 0.0656 & -0.223 & 0.1450 \\
\hline
\end{tabular}

In table 4 present results for test in difference in ROA between firms with high (60\% - 100\%) bank loans to those with low $(0 \%-30.99 \%)$ bank loan. Using Levene's test for equality of variances, the variances of these two groups are significantly different $(\mathrm{F}$-value $=5.024 ; \mathrm{p}$-value $=.033$. This applies when equal variances are assumed. 
Table 4: Table 3. Independent Samples Test for Difference in ROA between Firms with High Bank Loans to Those with Low Loans

\begin{tabular}{|c|c|c|c|c|c|c|c|c|c|c|}
\hline & \multicolumn{2}{|c|}{$\begin{array}{l}\text { Levene's Test } \\
\text { for Equality } \\
\text { of Variances }\end{array}$} & \multicolumn{7}{|c|}{ t-test for Equality of Means } \\
\hline & & \multirow[t]{2}{*}{$\mathrm{F}$} & \multirow[t]{2}{*}{ Sig. } & \multirow[t]{2}{*}{$\mathrm{t}$} & \multirow[t]{2}{*}{ df } & \multirow{2}{*}{$\begin{array}{l}\text { Sig. } \\
(2- \\
\text { tailed })\end{array}$} & \multirow{2}{*}{$\begin{array}{l}\text { Mean } \\
\text { Diffe- } \\
\text { rence }\end{array}$} & \multirow{2}{*}{$\begin{array}{l}\text { Std. } \\
\text { Error } \\
\text { Diffe- } \\
\text { rence }\end{array}$} & \multicolumn{2}{|c|}{$\begin{array}{l}95 \% \text { Confidence } \\
\text { Interval of the } \\
\text { Difference }\end{array}$} \\
\hline & & & & & & & & & Lower & Upper \\
\hline \multirow{2}{*}{$\begin{array}{l}\text { Return } \\
\text { on } \\
\text { Assets }\end{array}$} & $\begin{array}{c}\text { Equal } \\
\text { variances } \\
\text { assumed } \\
\end{array}$ & 5.024 & 0.03 & -2.15 & 28.0 & 0.040 & -0.076 & 0.035 & -0.149 & -0.004 \\
\hline & $\begin{array}{c}\text { Equal } \\
\text { variances } \\
\text { not } \\
\text { assumed }\end{array}$ & & & -1.22 & 3.19 & 0.305 & -0.076 & 0.062 & -0.268 & 0.116 \\
\hline
\end{tabular}

From the group statistics on table 4, firms with a low bank loan has a higher mean rate of return than those with high bank loan and the difference in ROA of -0.076 0r 7.6 percent for these groups is statistically significant, the t-test for equality of means is -2.15 , which is higher than the cut-off of +2 or -2 . Therefore, the data tell us that for these groups, there is the difference in performance (ROA) between listed with high loan and those with low loans. That is in terms of performance, bank loan has a discriminate firm's performance wise.

Table 5: Independent Samples Test for Difference in ROA between Firms with Medium Bank Loans to Those with Low Loans

\begin{tabular}{|c|c|c|c|c|c|c|c|c|c|c|}
\hline & \multicolumn{2}{|c|}{$\begin{array}{l}\text { Levene's Test } \\
\text { for Equality } \\
\text { of Variances }\end{array}$} & \multicolumn{7}{|c|}{ t-test for Equality of Means } \\
\hline & & \multirow[t]{2}{*}{$\mathrm{F}$} & \multirow[t]{2}{*}{ Sig. } & \multirow[t]{2}{*}{$\mathrm{t}$} & \multirow[t]{2}{*}{ df } & \multirow{2}{*}{$\begin{array}{l}\text { Sig. } \\
(2- \\
\text { tailed })\end{array}$} & \multirow{2}{*}{$\begin{array}{l}\text { Mean } \\
\text { Diffe- } \\
\text { rence }\end{array}$} & \multirow{2}{*}{$\begin{array}{l}\text { Std. } \\
\text { Error } \\
\text { Diffe- } \\
\text { rence }\end{array}$} & \multicolumn{2}{|c|}{$\begin{array}{l}95 \% \text { Confidence } \\
\text { Interval of the } \\
\text { Difference }\end{array}$} \\
\hline & & & & & & & & & Lower & Upper \\
\hline \multirow{2}{*}{$\begin{array}{l}\text { Return } \\
\text { on } \\
\text { Assets }\end{array}$} & $\begin{array}{c}\text { Equal } \\
\text { variances } \\
\text { assumed }\end{array}$ & 10.7 & 0.002 & -1.51 & 47 & 0.137 & -0.037 & 0.02 & -.08671 & .01230 \\
\hline & $\begin{array}{c}\text { Equal } \\
\text { variances } \\
\text { not assumed }\end{array}$ & & & -1.45 & 31.4 & 0.155 & -0.037 & 0.03 & -.08930 & .01489 \\
\hline
\end{tabular}

In table 5 are results for test in difference in ROA between firms with Medium (31\% - 59.9\%) bank loans to those with low $(0 \%-30.99 \%)$ bank loan. Using Levene's test for equality of variances, the variances of these two groups are significantly different (F-value is $10.72 ; \mathrm{p}$-value is 0.002 ).

From the group statistics on table 5, firms classified as of medium loan has a lower mean ROA than those classified as low bank loan, but the mean difference in ROA of -.037 or negative 3.7 percent between the groups is not statistically significant, because the t-test for equality of means has a sig. (2 - tailed) is -1.512 , which is less than the cut-off of +2 or -2 . Therefore, the data tell us that ROA is not different between these two groups.

3.1.2 Return on Equity (ROE) and Bank Loan

In table 6 , the average return to equity (ROE) for all groups is $9.90 \%$. The group in which $60 \%-100 \%$ ) of total assets are financed with a bank loan, that is the group with high bank loan, have an average ROE of 32.5 percent and it is the highest.

Table 6: Return to Equity (ROE) across Levels of Bank Loans

\begin{tabular}{|c|c|c|c|c|}
\hline Bank Loan Classification & $\mathrm{N}$ & $\mathrm{ROE}$ & Std. Deviation & Grouped Median \\
\hline High $(60 \%-100 \%)$ & 4 & 0.325 & 0.318 & 0.159 \\
\hline Medium $(31 \%-59.9 \%)$ & 23 & 0.009 & 0.503 & 0.105 \\
\hline Low $(0 \%-30.99 \%)$ & 26 & 0.146 & 0.142 & 0.028 \\
\hline All & 53 & 0.099 & 0.359 & 0.070 \\
\hline
\end{tabular}

The data tell us that when the performance measure is ROE, firms with a low bank loan to the total asset ratio outperform the other groups. Firms with medium bank loans level post the lowest ROE.

In table seven are results for test in difference in ROE between firms with high $(60 \%-100 \%)$ bank loans to those with medium (31\% - 59.9\%). Using Levene's test for equality of variances, with F- value of 0.017 and p- 
value of 0.897 is outside cut off value of 0.05 , the variances of these two groups are the same and not significantly different.

From the group statistics on table 7, firms classified as of high loan has a higher mean ROE than those classified median bank loans, but the mean difference in ROE of 0.316 or 31.6 percent between the groups is not statistically significant, because the t-test for equality of means has a t-value of 1.202, which is lower than the cutoff of +2 or -2 . Therefore, the data tell the performance of the firm, measured as ROE, is not different between the two groups, that is, bank loans have no discriminating effect..

Table 7. Independent Samples Test for Difference in ROE between Firms with Medium Bank Loans to Those with High Loans

\begin{tabular}{|c|c|c|c|c|c|c|c|c|c|}
\hline & \multicolumn{2}{|c|}{$\begin{array}{l}\text { Levene's Test for } \\
\text { Equality of } \\
\text { Variances }\end{array}$} & \multicolumn{7}{|c|}{ t-test for Equality of Means } \\
\hline & \multirow[t]{2}{*}{$\mathrm{F}$} & \multirow[t]{2}{*}{ Sig. } & \multirow[t]{2}{*}{$\mathrm{t}$} & \multirow[t]{2}{*}{ df } & \multirow[t]{2}{*}{$\begin{array}{l}\text { Sig. (2- } \\
\text { tailed) }\end{array}$} & \multirow{2}{*}{$\begin{array}{l}\text { Mean } \\
\text { Diffe- } \\
\text { rence }\end{array}$} & \multirow{2}{*}{$\begin{array}{l}\text { Std. Error } \\
\text { Differ- } \\
\text { ence }\end{array}$} & \multicolumn{2}{|c|}{$\begin{array}{l}95 \% \text { Confidence } \\
\text { Interval of the } \\
\text { Difference }\end{array}$} \\
\hline & & & & & & & & Lower & Upper \\
\hline $\begin{array}{l}\text { Equal } \\
\text { variances } \\
\text { assumed } \\
\end{array}$ & 0.017 & 0.897 & 1.202 & 25 & 0.241 & 0.316 & 0.263 & -0.225 & 0.856 \\
\hline $\begin{array}{l}\text { Equal } \\
\text { variances not } \\
\text { assumed }\end{array}$ & & & 1.659 & 6.035 & 0.148 & 0.316 & 0.19 & -0.149 & 0.781 \\
\hline
\end{tabular}

In table, eight are results for test in difference in ROE between firms with high $(60 \%-100 \%)$ bank loans to those with a low bank loan $(0 \%-30.99 \%)$. Using Levene's test for equality of variances, with F- value of 5.438 and $p$-value of 0.027 is within cut off value of 0.05 , the variances of these two groups are not the same and significantly different.

Table 8. Independent Samples Test for Difference in ROE between Firms with High Bank Loans to Those with Low Loans

\begin{tabular}{|c|c|c|c|c|c|c|c|c|c|}
\hline & \multicolumn{2}{|c|}{$\begin{array}{l}\text { Levene's Test for } \\
\text { Equality of } \\
\text { Variances }\end{array}$} & \multicolumn{7}{|c|}{ t-test for Equality of Means } \\
\hline & \multirow[t]{2}{*}{$\mathrm{F}$} & \multirow[t]{2}{*}{ Sig. } & \multirow[t]{2}{*}{$\mathrm{t}$} & \multirow[t]{2}{*}{ df } & \multirow[t]{2}{*}{$\begin{array}{l}\text { Sig. (2- } \\
\text { tailed) }\end{array}$} & \multirow{2}{*}{$\begin{array}{l}\text { Mean } \\
\text { Diffe- } \\
\text { rence }\end{array}$} & \multirow{2}{*}{$\begin{array}{l}\text { Std. } \\
\text { Error } \\
\text { Diffe- } \\
\text { rence }\end{array}$} & \multicolumn{2}{|c|}{$\begin{array}{l}95 \% \text { Confidence } \\
\text { Interval of the } \\
\text { Difference }\end{array}$} \\
\hline & & & & & & & & Lower & Upper \\
\hline $\begin{array}{l}\text { Equal } \\
\text { variances } \\
\text { assumed } \\
\end{array}$ & 5.438 & 0.027 & 1.954 & 28 & 0.061 & 0.178 & 0.09131 & -0.0086 & 0.365 \\
\hline $\begin{array}{l}\text { Equal } \\
\text { variances } \\
\text { not assumed }\end{array}$ & & & 1.107 & 3.188 & 0.345 & 0.178 & 0.16119 & -0.3178 & 0.675 \\
\hline
\end{tabular}

From the group statistics on table 8, firms classified as of high loan has a higher mean ROE than those classified as a low bank loan, but the mean difference in ROE of 0.178 or 17.8 percent between the groups is not statistically significant, because the t-test for equality of means has a t-value of 1.954, which is lower than the cutoff of +2 or -2 . Therefore, the data tell the performance of the firm, measured as ROE, is not different between the two groups, that is, bank loans have no discriminating effect.

In table 9 are results for test in difference in ROE between firms with Medium (31\% - 59.9\%) bank loans to those with low bank loan ( $0 \%-30.99 \%)$. Using Levene's test for equality of variances, with F- value of 3.979and p-value of 0.052 is outside cut off value of 0.05 , the variances of these two groups are the same. 
Table 9. Independent Samples Test for Difference in ROE between Firms with Medium Bank Loans to Those with Low Loans

\begin{tabular}{|c|c|c|c|c|c|c|c|c|c|}
\hline & \multicolumn{2}{|c|}{$\begin{array}{l}\text { Levene's Test } \\
\text { for Equality of } \\
\text { Variances }\end{array}$} & \multicolumn{7}{|c|}{ t-test for Equality of Means } \\
\hline & \multirow{2}{*}{$\mathrm{F}$} & \multirow{2}{*}{ Sig. } & \multirow{2}{*}{$\mathrm{t}$} & \multirow{2}{*}{ df } & \multirow{2}{*}{$\begin{array}{l}\text { Sig. } \\
(2- \\
\text { tailed })\end{array}$} & \multirow{2}{*}{$\begin{array}{l}\text { Mean } \\
\text { Differ- } \\
\text { ence }\end{array}$} & \multirow{2}{*}{$\begin{array}{l}\text { Std. Error } \\
\text { Differ- } \\
\text { ence }\end{array}$} & \multicolumn{2}{|c|}{$\begin{array}{l}95 \% \text { Confidence Interval } \\
\text { of the Difference }\end{array}$} \\
\hline & & & & & & & & Lower & Upper \\
\hline $\begin{array}{l}\text { Equal } \\
\text { variances } \\
\text { assumed } \\
\end{array}$ & 3.979 & 0.052 & -1.33 & 47 & 0.189 & $\begin{array}{c}- \\
0.1372\end{array}$ & 0.10291 & -0.3442 & 0.07 \\
\hline $\begin{array}{l}\text { Equal } \\
\text { variances } \\
\text { not } \\
\text { assumed }\end{array}$ & & & -1.26 & 25.12 & 0.218 & $\begin{array}{c}- \\
0.1372\end{array}$ & 0.10855 & -0.3607 & 0.086 \\
\hline
\end{tabular}

From the group statistics on table 9, firms classified as of low bank loan has a higher mean ROE than those classified as medium bank loans, but the mean difference in ROE of -0.137 or 13.7 percent between the groups is not statistically significant, because the t-test for equality of means has a t-value of -1.333 , which is lower than the cut-off of value of \pm 2 . Therefore, the data tell the performance of the firm, measured as ROE, is not different between the two groups, that is, bank loans have no discriminating effect.

\section{Summary of Findings and Conclusion}

The study set out to establish whether use of bank loan as a source of finance has the effect on performance of firms listed at NSE, Firms were grouped according to the amount of bank loans each firm used and then performance compared. The two measures of performance used were return on assets (ROA) and return on equity (ROE). The finding was that the discriminating effect of the bank loan on performance depends on the measure of firm performance. There was a significant difference in the ROA between firms classified as using high bank loan and those using low debts; and the return (ROA) of those firms using low debt was superior to other groups. There were no differences in return on equity across the three groups.

It is difficult concluding that bank loan influence performance. It is possible that banks offer services to their client indiscriminately. It is not important looking at the direction of the relationship between bank loan and performance because the data dismiss the existence of the relationship. In conclusion, firms cannot rely on bank loans and their relationship with bankers to edge out their competitors and earn superior returns. Firm must identify good products and services to generate revenue and earn good returns to shareholders.

\section{References}

Agnew, C. R. (2003). Commitment and its theorized determinants: A meta-analysis of the investment model.

Berger, A. N., \& Udell, G. F. (1998). The Economics of small business finance: the roles of private equity and debt market in the financial growth cycle. Journal of Banking and Finance, 22, 613-673.

Berger, A. N. and E. Bonaccorsi di Patti (2006), Capital Structure and Firm Performance: A New Approach to Testing Agency Theory and an Application to the Banking Industry, Journal of Banking and Finance, Vol. 30, pp.1065- 1102 .

Baum, C. F., Schafer, D. and Talavera, O. (2006). The Effects of Short-Term Liabilities on Profitability: A Comparison of German and US Firms', Working Papers in Economics No. 636, Boston College Department of Economics.

Baum C. F., Schafer D. \& Talavera O. (2007):’The Effects of Short-Term Liabilities on Profitability: The Case of Germany, Money Macro and Finance (MMF) Research Group Conference 2006 61, Money Macro and Finance Research Group.

Bolton, P., \& Freixas, X. (2000). Equity, Bonds, and Bank Debt: Capital Structure and Financial Market Equilibrium under Asymmetric Information. Journal of Political Economy, 108, 324- 351. http://dx.doi.org/10.1086/262121.

Boot, A. W. A. (2000). Relationship Banking: What Do We Know? Journal of Financial Intermediation, 9, 725.

Buch, C. (1998), "Toward universal banking \{risks and benefits for transition economies, competition and convergence in financial markets: the German and Anglo-Saxon models', Advances in Finance, Investment, and Banking and Finance Series 5.

Brigham, E. and Gapenski, L. (1996). Financial Management. Dallas: The Dryden Press.

Castelli, A., Dwyer, G. P. Jr., \& Hasan, I. (2006). Bank relationships and small firms' financial performance. 
Federal Reserve Bank of Atlanta. Working paper 2006-5.

Deloof, M., \& Vermoesen, V. (2010). The value of bank relationships: Evidence from Belgium at the start of the Great Depression. Working paper. University of Antwerp and Louvain School of Management.

Degryse, H., \& Ongena, S. (2001). Bank relationships and firm profitability. Financial Management Spring, 9-34.

Diamond, D. (1984). Financial Intermediation and Delegated Monitoring. Review of Economic Studies, 51, $393-$ 414. http://dx.doi.org/10.2307/2297430

Diamond, D. (1991). Monitoring and reputation: the choice between bank loans and privately placed debt. Journal of Political Economy, 99, 689-721. http://dx.doi.org/10.1086/261775

Eriotis, N.P. Franguoli, Z. and Z.V. Neokosmides (2002) "Profit Margin and Capital

Structure: An Empirical Relationship" The Journal of Applied Business Research 18, 85-89.

Fama, E.F. \& French, K.R. (2002). Testing trade off and pecking order predictions about dividends and debt, Review of financial studies, 15 (1), pp. 1-33.

Fok, C. W., Chang, Y. C., \& Lee, W. T. (2004). Bank relationships and their effects on firms' performance around the Asian financial crises: evidence from Taiwan .Financial Management, Summer, 89-112.

García Teruel, P. and P. Martinez Solano, 2008, On the Determinants of Cash Holding: Evidence from Spain, Journal of Business Finance \& Accounting, Vol. 35, Issue 1-2, pp. 127-149

Goddard et.al, 2005.Impact of Firm Level internal factors including age, size, growth, market share, leverage, capital intensity and liquidity on firm profitability.

Greenbaum, S., Kanatas, G. and Venezia, I. (1989). 'Equilibrium loan pricing under the Bank-client relationship.' Journal of Banking and Finance, vol. 13, pp. 221-35.

Hassan, H, Khan, F.and Wazir, M. (2016). Impact of Debt on Profitability of Firms; Evidence from Non-Financial Sector of Pakistan. City University Research Journal Vol. 06 No. 01, pp. 70- 80.

Hoshi, T., Kashyap, A., \& Scharfstein, D. (1991). Corporate structure, liquidity and investment: Evidence from Japanese industrial groups. Quarterly Journal of Economics, 106, 33-60.

Houston, J. and James, C. (1996). "Bank Information Monopolies and the Mix of Public and Private Debt Claims", Journal of Finance, Vol. 51, 1863-89.

James, C. (1987). Some evidence of the uniqueness of bank loans. Journal of Financial Economics, 19, $217-235$.

Jaramillo, F. and F. Schiantarelli (2002). Access to long Term Debt and Effects on firms' performance: lessons from Ecuador. IADB. Research Network Working Paper R-460.

Jensen M., Meckling W., 1976, Theory of the Firm: Managerial Behavior, Agency Costs, and Capital Structure, Journal of Financial Economics 76, 323-339.

Kutsuna, K., Smith, K. J., \& Smith, L. R. (2003). Banking Relationships and Access to Equity Capital Markets: Evidence from Japan's Main Bank System. Claremont Colleges. Working paper.

Kraus, A. \& Litzenberger, R.H. (1973).A State-preference model of optimal financial leverage, The Journal of Finance, 28 (4), pp. 911-922.

Mesquita M. and Lara E. (2003), Capital Structure and Profitability: The Brazilian Case, Vancouver: Academy of Business and Administration Sciences Conference, July 11-13, 2003.

Modigliani, F., \& Miller, M. H. (1958). The cost of capital, corporation finance and the theory of investment. 48(3), 261-297.

Modigliani F, Miller MH. 1963. Corporate income taxes and the cost of capital: a Correction. American Economic Review 53: 433-443

Myers, S. C. (1977). Determinants of corporate borrowing. Journal of Financial Economics, 5, 147-75.

Myers, S. C. \& Majluf, N. S. (1984). Corporate financing and investment decisions when firms have information that investors do not have. Journal of Financial Economics, 12, 187-221.

Ngobo P.V. and Capiez A. (2004): Structure du capital et performance de l'entreprise: le rôle modérateur des différences cultureless, Congrès de l'Association Internationale de Management Stratégique (AIMS), Le Havre.

OECD (Organization for Economic Co-operation and Development) (2005) Improving financial literacy: Analysis of issues and policies. Paris: OECD Publications.

Peltoniemi, J. (2004). The Value of Relationship Banking: Empirical evidence on small business financing in Finnish credit markets. Faculty of Economics and Business Administration, Department of Accounting and Finance, University of Oulu.

Petersen, M. and Rajan, R.G. (1995). "The Effect of Credit Market Competition on Lending Relationships", Quarterly Journal of Economics, Vol. 90, pp. 407-444.

Rajan, R. G. (1992). Insiders and outsiders: the choice between informed and arm's length debt. Journal of Finance, $47,1367-1400$.

Rungani, E. C. (2009). Determinants of Capital Structure of Small and Medium Enterprises in the Buffalo City Municipality, Eastern Cape Province, South Africa. MComm Thesis. University of Fort Hare, Alice.

Saunders, A. and Cornett, M. (February 7, 2018). Financial Markets and Institutions 7th Edition by (Author), 
Publisher: McGraw-Hill Education.

Sharpe, S. A. (1990). Asymmetric information, bank lending and implicit contracts: a stylized model of customer relationships. Journal of Finance, 45, 1069-1087.

Simerly RL, Li M. 2000. Environmental dynamism, capital structure and performance: a theoretical integration and an empirical test. Strategic Management Journal 21: 31-50.

Stewart III, G. B. (1991). The quest for value: A guide for senior managers. New York: HarperCollins

Suwanaporn, C. (2003). Determinants of Bank Lending in Thailand: An Empirical Examination for the Years 1992 to 1996. Peter Lang Publishing.

Schiffer, M. and Weder, B. (2001). Firm Size and the Business Environment Worldwide Survey Results. International Finance Corporation (Discussion Paper), FD43.

Teruel, P.J.G. and Solan, P.M. (2007). Effect of Working Capital Management on SME Profitability. Internatrional Journal of Managerial Finance, Vol. 3, PP.164-177.

Von Thadden, E.L. (1995). Long term contracts, short term investments and monitoring.ReviewofEconomicStudies.67557 575.https://dx.doi.org/20.2307/2298077.

Wanjohi, A.M. and Mugure, A. (2008). Factors affecting the growth of MSEs in rural areas of Kenya: A case of ICT firms in Kiserian Township, Kajiado District of Kenya.

Weill, L. (2008) .Leverage and Corporate Performance: Does Institutional Environment Matter? Small Business Economics, 30:.251-265. 